\title{
Hacía una historia de la izquierda chilena desde una perspectiva transnacional: La vía chilena al socialismo y los procesos políticos latinoamericanos, 1952-1970
}

Towards a history of the Chilean Left from a transnational perspective: the Chilean path to Socialism and the Latin-American political processes, 1952- 1970

\author{
Claudio Pérez Silva*
}

Resumen: Esta propuesta de investigación, problematiza la historia de la izquierda chilena a partir de una perspectiva transnacional, poniendo énfasis en la recepción y resignificación de procesos políticos latinoamericanos desarrollados entre la década del cincuenta y sesenta del siglo pasado. Al respecto, planteamos que la construcción programática de la izquierda y su proyecto de "vía chilena al socialismo", se vio permeada y alimentada por debates, experiencias y formulaciones políticas emanadas desde otras latitudes del continente. Así, las diversas recepciones de estos procesos políticos por parte de la izquierda chilena, se convirtieron en importantes insumos de discusión en torno a problemáticas vinculadas al carácter de la revolución y la construcción programática y estratégica.

Palabras clave: Vía chilena al socialismo, recepción, comunismo, socialismo, historia transnacional, latinoamericanismo.

\begin{abstract}
This research proposal, problematizes the history of the Chilean Left from a transnational perspective, emphasizing the reception and resignification of Latin-American political processes developed between the fifties and sixties of last century. About this matter, we conceive that the programmatic construction of the left and its project of the "Chilean path towards socialism", was permeated and nourished by debates, experiences and political formulations emanated from other latitudes of the continent. Thus, the diverse receptions of these political processes in the Chilean left, became important instruments for the discussion around problematics linked to the character of the revolution and strategic and programmatic construction.
\end{abstract}

Key words: Chilean path towards socialism, reception, communism, socialism, transnational history, Latin Americanism.

Recibido: 7 julio 2018 Aceptado: 12 septiembre 2018

\footnotetext{
* Chileno. Académico Instituto de Historia y Ciencias Sociales, Universidad de Valparaíso, Chile. Este trabajo forma parte del proyecto de investigación FONDECYT No 11161095: "La izquierda chilena al alero de los procesos políticos latinoamericanos. Recepción y reconfiguración programática, 1949-1970”. Mail: claudioperezsilva@gmail.com
} 
En la última década, la historiografía sobre la izquierda ha experimentado un notable crecimiento. Novedosas y profusas investigaciones han convertido a la izquierda chilena en una importante preocupación académica con un amplio campo de estudio. Lo anterior, producto de su importancia política, la multiplicidad de expresiones, actores que la representan y espacios de intervención (sociales, políticos, culturales, artísticos, internacionales), así como una larga trayectoria histórica, incluso sorteando y manteniendo su protagonismo a pasar de las dinámicas y políticas represivas que buscaron su desaparición. Lo anterior, también ha llamado la atención investigativa de otras disciplinas, como la Antropología, Psicología, Sociología y la Ciencia Política, posibilitando con ello, una riqueza de acercamientos teóricos metodológicos de carácter multidisciplinario, así como la formulación de interesantes debates y complejas interpretaciones sobre su trayectoria histórica ${ }^{1}$.

Varios aspectos han favorecido los estudios sobre la izquierda chilena. A nivel global, el descubrimiento, acceso y utilización de nuevas e importantes fuentes documentales (nacionales e internacionales), así como la emergencia de archivos sobre las izquierdas, han permitido adentrarse en una diversidad de temáticas, espacios, actores y problemas teóricos-políticos que emergen de ellas ${ }^{2}$. Otros factores a considerar en este crecimiento, ya desde el campo historiográfico particularmente, son la ampliación de los periodos históricos en estudio y, sobre todo, las nuevas metodologías y enfoques teóricos utilizados para dar cuenta de su trayectoria. Destacan en este sentido las miradas centradas en la trayectoria militante, los debates y las tensiones políticas, los procesos de politización, las diversas expresiones del movimiento popular y su vinculación con la izquierda (campesinos, movimiento obrero, pobladores, mapuches, artistas e intelectuales, mujeres, estudiantes, etc.), los aspectos identitarios y las culturas políticas creadas, las redes políticas e intelectuales y las experiencias internacionalistas, entre otros muchos aspectos.

Por otro lado, el estancamiento-agotamiento de la historia social que invisibilizó y cuando no desechó abiertamente las expresiones y dimensionas políticas de los sectores populares ${ }^{3}$, así como el escenario creciente de movilizaciones sociales que experimentó nuestro país, aproximadamente desde el año 2006 en adelante, con la irrupción de los trabajadores subcontratados del cobre, salmoneros, portuarios, forestales, el dinámico y masivo movimiento estudiantil, han resituado la importancia de lo "político" dentro del conflicto social, favoreciendo con ello una mirada retrospectiva y problematizadora sobre la propia trayectoria del movimiento popular chileno, particularmente en cuanto a la relación entre lo social y lo político.

En la misma línea, la necesidad de comprender el pasado reciente, marcado por la formulación de proyectos históricos (políticos) en abierta disputa; el terror de la dictadura y el despliegue de su proyecto societal; la oposición y resistencia a ella, así como el carácter de la transición a la democracia, han beneficiado la preocupación por lo político dentro del campo historiográfico y, particularmente, respecto al papel jugado por la izquierda chilena en todos estos procesos ${ }^{4}$.

1 Rolando Álvarez, "Historia e historiografía del comunismo: debates y nuevos enfoques", Revista de Historia Social y de las Mentalidades, $\mathrm{N}^{\circ} 2,21$, Santiago, 2017, 11-29.

2 Álvarez, op.cit., p. 13; Barry Carr, "Escribiendo la historia de los comunismos en las Américas: Retos y nuevas oportunidades", Patricio Herrera (Coordinador), El Comunismo en América Latina. Experiencias militantes, intelectuales y transnacionales (1917-1955), Valparaíso, Universidad de Valparaíso, 2018, 13-32; Sergio Grez, "Comunismo chileno e Historiografía: un par de observaciones”, Olga Ulianova; Rolando Álvarez y Manuel Loyola (editores), 1912 - 2012 El Siglo de los Comunistas, Santiago, IDEA-USACH, 2012, 13-21.

${ }^{3}$ Grez, op. cit., p. 14; Sergio Grez, "Escribir la historia de los sectores populares. ¿Con o sin la política incluida? A propósito de dos miradas a la historia social", Revista Política, 44, Santiago, 2005, 17-31; Historia del comunismo en Chile, Santiago, LOM, 2011; José Ponce y Aníbal Pérez "La revitalización de la historiografía política chilena", POLIS revista Latinoamericana, 12, №36, Santiago, 2013, 453-476.

4 Danny Monsálvez, "La dictadura militar de Augusto Pinochet como Nueva Historia Política: Perspectiva historiográfica y algunos temas para su indagación", Revista Austral de Ciencias Sociales, 23, Valdivia, 2012, 61-82 y "La historia reciente en Chile: un balance desde la nueva historia política historia", 396 No 1, 6, Viña del Mar, 2016, 111-139; Rolando Álvarez, "Historias, 
Los factores mencionados anteriormente, se vieron beneficiados igualmente por lo que en el campo historiográfico se ha denominado "la vuelta de la Historia Política" (nueva), lo cual ha implicado la extensión de los marcos temporales de estudio, el trabajo interdisciplinario y, sobre todo, la revitalización de los estudios sobre las experiencias políticas de los sectores populares, así como la revisión-problematización de la propia historia de la izquierda chilena bajo nuevas preguntas y perspectivas analíticas, abriendo con ello, un abanico de posibilidades para conocer y comprender las múltiples formas en las que se expresa lo político y la política: Militancia, subjetividades, culturas políticas, recepción de ideas, reconfiguración política y emergencia de proyectos ${ }^{5}$.

Estos significativos logros y reconocimientos en términos de producción académica e impacto historiográfico, son posibles de identificar a través de la voluminosa cantidad de tesis de pre y posgrado desarrolladas en universidades nacionales y extranjeras, así como en la diversidad de seminarios, congresos, proyectos de investigación y publicaciones que han tenido como objeto de estudio a las izquierdas chilena ${ }^{6}$.

No obstante, estos importantes avances, los cuales traen consigo la ampliación de sujetos y procesos políticos objetos de ser estudiados, la gran mayoría de los trabajos relacionados con la trayectoria de las izquierdas chilenas aborda a dichos actores, estructuras partidarias, culturas políticas, subjetividades, motivaciones y formulación de proyectos políticos, a partir de enfoques teóricos metodológicos, dinámicas políticas y escenarios estrictamente locales o nacionales.

Salvo los trabajos de Olga Ulianova, Alfredo Riquelme y Joaquín Fernández ${ }^{7}$, la gran mayoría de las investigaciones sobre la izquierda chilena, por los enfoques, experiencias y espacios de intervención estudiados, actores indagados, así como por las preguntas y conclusiones que emanan de ellas, tienden a

historiografía y memorias del comunismo chileno en la primera década del siglo XXI”, Viviana Bravo, ¿Con la razón y la fuerza, venceremos! La Rebelión Popular y la Subjetividad Comunista en los '80, Santiago, Ariadna, 2010, 11-30; Cristina Moyano, "La historia política en el bicentenario: entre la historia del presente y la historia conceptual. Reflexiones sobre la nueva historia política", Revista de Historia Social y de las Mentalidades, N 1, 15, 2011, 227-245.

${ }^{5}$ Cristina Moyano, op. cit; Olga Ulianova, "La historia política está de vuelta", Olga Ulianova (ed), Redes política y militancia. La bistoria política está de vuelta, Santiago, Ed. Ariadna-IDEA, 2009. 9-18; Ponce, op. cit., 453-476.

${ }^{6}$ Las Jornadas de Historia de las izquierdas en Chile (2008, 2010, 2012, 2014), así como en las permanentes actividades académicas que congregan de manera periódica a historiadores nacionales (Jornadas de Historia Regional de Chile y Jornadas de Historia de Chile) en donde la presencia de mesas o simposios en las cuales se exponen las nuevas investigaciones sobre la historia de las izquierdas chilena, son una pequeña muestra de lo estamos señalando. Misma afirmación podemos realizar respecto a la significativa adjudicación de proyectos de investigación FONDECYT durante la última década, en los cuales la problemática principal de estudio es la trayectoria y la experiencia histórica de la izquierda chilena.

${ }^{7}$ Olga Ulianova, "Relaciones Internacionales y redefiniciones en el socialismo chileno 1973-1979”, Revista Izquierdas, N 4, 2009 , 1-30; "Develando un mito: emisarios de la Internacional Comunista en Chile", Historia, No 41, V. I, 2008, 99-164; "La nueva inserción internacional del comunismo chileno tras el golpe militar", Alfredo Riquelme y Tanya Harmer, Chile y la guerra fría global, RIL Editores-Instituto de Historia UC, 2014, 273-315; "El comunismo chileno a través de los archivos soviéticos". Augusto Varas et al. (comps), El Partido Comunista en Chile, Santiago, Catalonia/USACH/FLACSO, 2010; "Reflexiones sobre la Guerra Fría desde el fin del mundo", Fernando Purcell, Alfredo Riquelme, Ampliando miradas, Chile y su historia en el tiempo global. Santiago, RIL-UC, 2009, 235-259; "Entre el auge revolucionario y los abismos del sectarismo: el PC chileno y el Buró Sudamericano de la Internacional Comunista 1932-1933”, Rolando Álvarez, Augusto Samaniego, Hernán Venegas eds. Fragmentos de una historia. El Partido Comunista de Chile en el siglo XX. Democratización, clandestinidad, rebelión (1921-1994). Santiago, Ediciones ICAL, 2008, 52-90; Olga Ulianova y Alfredo Riquelme. Chile en los archivos soviéticos. Vol. 1 1922-1931, Santiago, LOM/USACH/Centro de Investigaciones Barros Arana, 2005; Olga Ulianova y Alfredo Riquelme. Chile en los archivos soviéticos. Vol. 2 1931-1935, Santiago, LOM/USACH/Centro de Investigaciones Barros Arana, 2009; "Levantamiento campesino de Lonquimay y la Internacional Comunista", Estudios Públicos, Nº 89, Santiago, 2003, 173-223; Alfredo Riquelme, "La Guerra Fría en Chile: los intrincados nexos entre lo nacional y lo global", Alfredo Riquelme y Tanya Harmer, Chile y la guerra fría global, RIL Editores-Instituto de Historia UC, 2014, 11-43; Alfredo Riquelme, Un rojo atardecer. El comunismo chileno entre dictadura y democracia. DIBAM. Santiago, 2009; Joaquín Fernández, "En lucha contra el "pulmón de la conspiración fascista en América Latina". Los comunistas chilenos ante el proceso político argentino y el Gobierno de la Revolución de Junio (1943-1946)", Revista Historia, N 48, II, 2015, 435-463; "Orígenes de un desencuentro: El Partido Comunista de Chile ante el Movimiento Nacionalista Revolucionario y la dictadura de Villarroel en Bolivia (1943-1946), Revista de Historia Socialy de las Mentalidades, N 1, 19, 2015, 9-39; "Nacionalismo y Marxismo en el Partido Socialista Popular (1948-1957)", Irquierdas, No 34, 2017, 26-49. 
reforzar "el particularismo chileno" tan ampliamente desarrollado a nivel macro por la historiografía tradicional chilena, la cual establece un inusual camino propio de la dinámica nacional respecto de la realidad latinoamericana en general, estableciendo con ello una serie de mitos relativos a la temprana creación del Estado-Nación chilena, la larga estabilidad política institucional, ajena a los hechos o ciclos de violencia política, característicos y endémicos en países de la región; la ausencia de populismo; el constitucionalismo de las fuerzas armadas chilenas, la práctica y tradición democrática de las clases dominantes y la derecha chilena, la inexistencia de la corrupción, entre otros aspectos de la vida nacional.

En cuanto a nuestro caso particular de estudio, esta tendencia explicativa presenta la formulación y desarrollo de "la vía chilena al socialismo" por parte de los principales partidos de la izquierda chilena (socialista y comunista), como una posibilidad y una muestra más de ese particularismo. Como una experiencia y proceso político de construcción eminentemente nacional, con un gran protagonismo de actores y estructuras nacionales (jurídica-política), posible de realizar y proyectarse gracias a las tradiciones y dinámicas políticas estrictamente locales, las cuales habrían permitido la formulación y despliegue de este proyecto único en el mundo por parte de la izquierda chilena.

Nuestra propuesta de investigación, busca justamente problematizar estas lecturas y comprender la trayectoria de la izquierda chilena durante el proceso de formulación de su proyecto estratégico, a partir de un escenario político más amplio de análisis, que considere los procesos, las transformaciones económicas-sociales y los conflictos político regionales, la movilidad y conexión de la izquierda chilena con las principales dinámicas y experiencias políticas latinoamericanas.

En definitiva, proponemos investigar, en el marco de la articulación de alianzas y frentes electorales, de construcción de fuerzas políticas-sociales y de formulación del proyecto programático y estratégico de la izquierda chilena (1952-1970), la vinculación, recepción y re-significación realizada por ésta, respecto de procesos políticos que trascendieron las propias fronteras nacionales en donde se presentaron, ya sea por el significado de las transformaciones llevadas adelante o por los vínculos y debates políticos que se generaron a partir de ellos, cruzando y conectando la historia de nuestro continente, entre 1950 y 1970.

De esta manera, bajo los marcos conceptuales y metodológicos propuestos por la nueva historia política y la historia transnacional, buscamos estudiar e inscribir la trayectoria histórica de la izquierda chilena en un marco interpretativo de relaciones causales más amplio, en una dimensión global, bajo un análisis que implica vinculación, recepción y reconfiguración de sus postulados y apuestas a partir de la incidencia-apropiación de procesos políticos que se desarrollaban en paralelo en la región ${ }^{8}$. Creemos posible, adentrarnos en la trayectoria de la izquierda chilena a partir de la experiencia vivida por la izquierda latinoamericana, insertando con ello, los problemas, debates y desafíos enfrentados por comunistas y socialistas dentro de una dinámica y espacio común transfronterizo durante el periodo en estudio.

La historia transnacional nos entrega sustanciales aportes teóricos metodológicos, al desbordar la exclusividad de factores nacionales e invitarnos a reflexionar e investigar desde una perspectiva relacional, los movimientos, la integración, el entrelazamiento y las circulaciones entre lugares y regiones, entre lo nacional y lo global, ayudándonos por tanto, a complementar o superar en algunos casos, las

\footnotetext{
8 Riquelme y Harmer, op. cit., Florencia Peyrou y Darina, Martykanova, “La historia transnacional”, Revista Ayer, N², 94, 2014,1322; Oliver Dabene, La Region Amérca Latine. Interdependance et changement politique, París, Presses de Sciences Po, 1997; Eduardo Zimmermann, "Estudio Introductorio. Una nota sobre nuevos enfoques de historia global y transnacional", Estudios Sociales del Estado, N 5, 3, Buenos Aires, 2017, 12-30; María Cristina Pérez, "Redes y conexiones en la historia", Historia Crítica, N 55, Bogotá, 2015, 13-17; Hugo Fazio, "La historia global y su conveniencia para el estudio del pasado y del presente", Historia Crítica, N 39 E, Bogotá, 2009, pp. 300-319; José Bendicho, Comparación e historia transnacional: ¿cuál es su pertinencia para el estudio del hispanismo en Latinoamérica? Taller de Discusión "Las derechas en el Cono Sur, siglo XX”, Universidad Nacional de General Sarmiento, 2012; Romain Bertrand, ¡Historia global, historias conectadas: ¿un giro historiográfico?”, Probistoria, Buenos Aires, N 24, 2015, 3-20.
} 
miradas e interpretaciones estrictamente nacionales que recaen sobre la trayectoria y protagonismo político de la izquierda chilena9.

Buscamos identificar los influjos y tensionamientos latinoamericanos en el desarrollo histórico de la izquierda chilena y su proyecto estratégico, mayormente explicado hasta el momento, a partir de su experiencia histórica particular en cuanto a sujetos y fuerzas sociales que dice representar (clase trabajadora) o dando cuenta de la exclusividad del régimen político chileno en comparación a nuestros vecinos latinoamericanos (larga institucionalidad y orden), la cual habría posibilitado la temprana emergencia, participación, despliegue e institucionalización de la izquierda chilena, fraguando así su carácter y tradición legalista, así como su enorme peso político nacional.

Al respecto, es posible observar también, que una parte significativa de lecturas y apuestas investigativas sobre la izquierda chilena, no contemplan en sus estudios, elementos centrales de la propia configuración política e ideológica de comunistas y socialistas, como son las dimensiones internacionalistas y latinoamericanistas respectivamente. Así, un partido, como el comunista, de carácter internacionalista, el cual analiza, se sitúa e interviene en la realidad local bajo una concepción internacional del conflicto de clases, contiene en su despliegue político, táctico y estratégico, en la práctica solidaria e internacionalista, evaluaciones desarrolladas por éstos, en cuanto a diagnósticos y apuestas levantadas por otras agrupaciones de izquierda respecto de problemáticas económicas-sociales o procesos políticos desencadenados al mismo tiempo y de manera conectada en nuestro continente. Procesos en los cuales, incluso, la clase obrera y los propios partidos comunistas de la región se veían involucrados o tenían un gran protagonismo ${ }^{10}$.

Misma situación podemos observar en el caso del socialismo chileno, donde a partir de sus diagnósticos y propias definiciones políticas, su simbología, construcción identitaria y redes políticas principales, es posible identificar y destacar el carácter latinoamericanista de su concepción política y la traducción de ésta en el despliegue de su política a nivel nacional y global ${ }^{11}$.

Tomando en cuenta estos elementos configuradores de la política comunista y socialista, consideramos de enorme utilidad las aportaciones de la historia trasnacional y la historia global. Éstas, en términos generales nos permiten salir del confinamiento nacional interpretativo y escudriñar en las historias conectadas, en las vinculaciones entre sujetos con las mismas concepciones políticas, pero en espacios geográficos más amplios y comunes que subvierten lo local, estatal y nacional. Bajo esta mirada, las historias de comunistas y socialistas se nos presentan como historias múltiples y en plural.

La perspectiva transnacional nos permite observar los procesos políticos, como la formulación de la vía chilena al socialismo, desde diversas opciones metodológicas, resaltando eso sí, las interconexiones, sobrevolando las fronteras estatales y enfatizando en "las redes, los procesos, las creencias y las instituciones, trascendiendo el espacio nacional" 12 . Por ejemplo, identificando y resaltando los movimientos y las circulaciones de socialistas y comunistas en nuestro continente, los exilios y la

\footnotetext{
${ }^{9}$ Conrad, Sebastían. Historia Global. Una nueva visión para el mundo actual, Barcelona, Crítica, 2017, pp. 9-11; María Coelho, “América Latina: Historia comparada, historias conectadas, historia transnacional”, Anuario N²4, Revista Digital No 3, Rosario, 2011 2012, p. 19.

10 Grez, op. cit., 13-21.

${ }^{11}$ Fabio Moraga, “¿Un partido indoamericanista en Chile? La Nueva Acción Pública y el Partido Aprista Peruano (1931-1933)”, Revista histórica, No 33, Lima, 2009, 109-156; Julio Jobet, El Partido Socialista de Chile, Santiago, Prensa Latinoamericana 1972; Julio Jobet y Alejandro Chelen, Pensamiento teórico y político del Partido Socialista de Chileno, Santiago, Editorial Quimantú, 1972; Paul Drake, Socialismo y populismo en Chile, 1932-1970, Valparaíso, Universidad Católica de Valparaíso, 1992; Olga Ulianova, "Inserción internacional del socialismo chileno 1933-1973", Olga Ulianova (ed), Redes política y militancia. La bistoria política está de vuelta, Santiago, Ariadna-IDEA, 2009, 235-284; Juan Reveco, "Influencia del APRA en el Partido Socialista de Chile", Vida y obra de Victor Raúl Haya de la Torre. Lima, Instituto Cambio y Desarrollo, 2006, 19-134; Joaquín Fernández, op. cit., 26-49; Sebastián Hernández, "Apristas en Chile: circuitos intelectuales y redes políticas durante los años 1930", Revista de Historia y Geografía, No 31, Santiago, 2014, pp. 77-94; Ignacio Walker, "Democracia, Populismo y Leninismo: El Partido Socialista de Chile (1933-1973)", Ignacio Walker, Socialismo y democracia. Chile y Europa en perspectiva comparada, CIEPLAN, Santiago, 1990, pp.117-171.

${ }^{12}$ Coelho, op. cit., p. 19.
} 
recepción de exiliados en Chile, analizar sus trayectorias y dinámicas políticas en desplazamientos, entre un lugar nacional y un contexto y espacio regional.

Sostenemos al respecto, que la configuración de una militancia o identidad de izquierda en Chile, al verse permeada por las dinámicas y apuestas políticas de la izquierda latinoamericana, en algunos aspectos bajo problemas y experiencias comunes, también se construyó o se formó desde una dimensión latinoamericana e internacional. El ser de izquierdas en Chile también consideraba una serie de elementos y dimensiones latinoamericanas, una muestra y aspecto clave y estructurante de ello, es el carácter antimperialista y anti oligárquico de sus concepciones y apuestas políticas comunes. De igual forma, la defensa de la soberanía nacional, la autonomía de los pueblos, la reforma agraria y la nacionalización de los recursos naturales se convirtieron en reivindicaciones nacionales y demandas latinoamericanas del conjunto de la izquierda a la vez ${ }^{13}$. Por tanto, la identidad de la izquierda chilena se alimentó y desarrolló de forma paralela tanto en Chile como en el espacio Latinoamericano.

El dominio de las historias nacionales concentradas en el resalte del proceso de construcción de Estado nación (nacionalismo metodológico) ${ }^{14}$ y la subsecuente obsesión por explicar e inscribir históricamente la trayectoria de la izquierda chilena en las dinámicas nacionales ha tendido a considerar inexistente este aspecto formativo. De ahí que proponemos develar los problemas, debates y argumentos comunes respecto a las cuestiones latinoamericanas. Estas dinámicas, acompañadas por contactos individuales, informales y oficiales entre partidos, desplegadas con solidaridades e internacionalismo, favorecen la idea de construcción común de la izquierda en el continente, más allá de la frontera nacional, sin negar, por cierto, las particularidades, los escenarios, actores y las experiencias nacionales en su proceso de configuración.

La formación de la izquierda chilena y los problemas estructurales de la sociedad latinoamericana, sobre todo desde la década de 1930 en adelante, hicieron que los diagnósticos y las apuestas se interconectaran y fueran en gran medida comunes en el continente. Los procesos y las estrategias de liberación nacional y popular, de carácter antiimperialista, se transformaron en un elemento central y articulador en la configuración de una izquierda latinoamericana, contorneando de esta manera una identidad y una cultura común.

Socialistas y comunistas abogaron por la universalidad de sus apuestas, al mismo tiempo levantaron y fortalecieron identidades y apuestas nacionales, tanto dentro como fuera de Chile. Lo anterior no es contradictorio si entendemos el nacionalismo y el antiimperialismo, así como el latinoamericanismo e internacionalismo como expresión política de una realidad común. En este sentido, la solidaridad dentro de la izquierda latinoamericana, entendida ampliamente como solidaridad entre pueblos oprimidos, ayudó a fortalecer los proyectos políticos globales o universales, como el socialismo, transformándose esta práctica y concepción en uno de los aspectos más visibles que cruza y subvierte las fronteras nacionales e ideológicas del estado nación y las historias nacionales. De ahí nuestra preocupación por los movimientos y las trasmisiones, los contactos y vínculos; las redes militantes, los exilios y "la circulación de personas, ideas, discursos y bienes, desde la firme convicción de que los procesos históricos se construyen a través de esos movimientos constantes que atraviesan territorios, espacios y regiones"15.

La inscripción internacional de socialistas y comunistas chilenos a una cultura política global es significativamente importante para considerarla una aportación en la explicación de sus trayectorias nacionales. De igual manera, es importante considerar, que las culturas políticas "debido a la incesante circulación de personas, imágenes e ideas, nunca están constreñidas a un ámbito nacional, sino que

\footnotetext{
13 Mauricio Archila, "La izquierda hoy: reflexiones sobre su identidad", Encuentro Marx Vive, Bogotá, Universidad Nacional, 2007, 23-44; Gerardo Necoechea, "Experiencia, ideología y proceso de politización en las historias orales de militancia de izquierda durante la segunda mitad del siglo XX", Pablo Pozzi (coord.), Rebeldes e Inconformistas. Procesos de politización y rebelión en América Latina, Buenos Aires, CLACSO-ImagoMundi, 2016, 13-34.

14 Conrad, op. cit., p. 10.

15 Peyrou y Martykanova, op. cit., p. 19.
} 
siempre constituyen espacios más amplios, abiertos y sin límites fijos"16. Bajo este marco, la izquierda chilena, al estar sometida a relaciones y reciprocidades, observa y recepciona discursos, diagnósticos, análisis, manifiestos, apuestas y proyectos políticos desplegados por otros militantes de izquierda en la región, los cuales impactan e influyen en diversos lugares y actores, operando sobre las concepciones políticas, las identidades colectivas militantes, en las formas de lucha y organización, así como en el proceso de elaboración programática y estratégica.

En el caso de los estudios sobre la izquierda chilena en el proceso histórico de construcción de su proyecto estratégico, compartimos las reflexiones de Carmen De la Guarda y Juan Pan-Montojo, quienes proponen readecuar los espacios de estudios por el objeto de investigación elegido. Consecuentemente, las preguntas sobre la trayectoria de "la vía chilena al socialismo" serán formuladas desde la conexión de la izquierda chilena con los procesos políticos y de transformaciones experimentados en nuestro continente ${ }^{17}$. Resaltando con ello, las vinculaciones de las condiciones particulares-nacionales, con las dinámicas y escenarios regionales y globales que se articularon en la configuración y despliegue del proyecto estratégico de socialistas y comunistas en torno a la vía pacífica al socialismo.

De esta manera, el estudio de la recepción de ideas y procesos políticos o de solidaridades con otras apuestas y experiencias de lucha que sacudieron a nuestro continente entre la década del cincuenta y el sesenta del siglo pasado, permitirá complementar las visiones e interpretaciones levantadas hasta ahora respecto al desarrollo histórico de la izquierda chilena.

En cuanto a la producción académica sobre la izquierda chilena, arbitrariamente establecemos dos grandes nudos productivos y temporales. El primero, aborda las problemáticas relacionadas con el proceso fundacional de los partidos de izquierda hasta la crisis del Frente Popular y la ilegalización del PCCh. Acá encontramos un primer grupo de trabajos bajo la hegemonía de la historiografía marxista y la historia política tradicional. Estas investigaciones en su gran mayoría, fueron desarrolladas entre 1950 y 1960 por historiadores militantes, a partir de fuentes oficiales pertenecientes a estas colectividades. En ellas, se abordaron las distintas tácticas y estrategias políticas, la política de alianzas, los debates internos y vínculos internacionales, construyendo a partir de ellas diversas etapizaciones e interpretaciones de la trayectoria partidaria ${ }^{18}$.

En la misma línea, estos trabajos destacan la adopción oficial de determinadas líneas y estrategias, así como un desarrollo disciplinado, homogéneo y continuo del devenir militante y partidario, opacando por contraste, las discusiones, tensiones y contradicciones surgidas en el diseño de las tácticas de periodo, la elaboración programática y la puesta en práctica de sus políticas.

En otro sentido, la historia social y la nueva historia política han contribuido significativamente a la ampliación y comprensión del recorrido histórico tanto del movimiento popular como de la izquierda chilena, dando cuenta de los procesos identitarios y de politización de la clase trabajadora, la relación con el Estado y los espacios de intervención política, las diversas formas organizativas y de luchas; el papel de las corrientes socialistas en la construcción del movimiento popular, así como la emergencia de las primeras estructuras partidarias. En la misma línea, estos investigaciones ensancharon notablemente los conocimientos sobre la militancia socialista-comunista desde la década de 1920 en adelante a partir del estudio de la experiencia y obra de Recabarren, mostrándonos las diversas formas en las cuales se

16 Ibid. p. 20.

17 Carmen de la Guardia y Juan Pan-Montojo, "Reflexiones sobre la historia transnacional”, Studia Histórica, Historia Contemporánea, 16, Salamanca, 1998, 9-31.

${ }_{18}$ Fernando Casanueva y Manuel Fernández, El Partido Socialista y la lucha de clase en Chile, Santiago, Quimantú, 1973; Alejandro Chelén, Trayectoria del socialismo, Buenos Aires, Austral, 1968; Julio César Jobet, op. cit., 1972; Hernán Ramírez, Origen y formación del Partido Comunista de Chile, Santiago, Progreso, 1984. 
desarrolló la militancia; su cultura política; la reconfiguración de las prácticas organizativas de la clase trabajadora y las principales vertientes políticas e ideológicas que nutrieron su concepción política ${ }^{19}$.

Bajo estas mismas aportaciones, pero resaltando elementos de la construcción identitaria y la cultura política de la militancia comunista, encontramos una serie de trabajos que analizan las tradiciones organizativas y el modo de ser comunista, las principales tensiones y discusiones partidarias en el marco de la crisis del régimen oligárquico y su despliegue político durante el Frente Popular, así como las características y proyecciones de su política de alianzas ${ }^{20}$.

En cuanto al socialismo chileno, podemos observar importantes estudios que dan cuenta de sus orígenes, la política de alianzas y la construcción partidaria, así como la configuración política e ideológica de la militancia socialista. En gran parte de ellos, se destaca el carácter populista y reformista del PS a la hora de explicar sus constantes contradicciones entre teoría y práctica y sus sucesivos zigzagueos políticos durante el proceso de incorporación al Estado y régimen político ${ }^{21}$.

Lo interesante de estos estudios en relación a nuestro tema de investigación, es que incorporan al análisis de la configuración y trayectoria del socialismo chileno los tempranos y fuertes vínculos entre el socialismo chileno y otras organizaciones y experiencias populistas a nivel latinoamericano. Este último aspecto ha sido desarrollado por Fabio Moraga, quien, desde una historia de las ideas o historia intelectual, abordó la temática de los influjos culturales del "indoamericanismo" y el "anti-imperialismo" como matrices compartidas y reforzadas por organizaciones como el APRA peruano o procesos como el de Lázaro Cárdenas en México, a la hora de explicar la identidad y cultura política del socialismo chileno. En la misma línea, este autor ha aportado estudiando la vanguardia juvenil y estudiantil de las primeras décadas del siglo XX, para dar cuenta de la llegada y difusión de las ideas socialistas y revolucionarias, y su rol en la fundación del Partido Socialista22.

En cuanto al PCCh, Olga Ulianova es quien preferentemente y en numerosas investigaciones ha estudiado este partido desde una perspectiva global, acercando y comprendiendo la trayectoria de su

19 Julio Pinto y Verónica Valdivia, ¿Revolución proletaria o querida chusma? Socialismo y alessandrismo en la pugna por la politización pampina (1911-1932), Santiago, LOM, 2001; Julio Pinto, Luis Emilio Recabarren. Una biografía bistórica, Santiago, LOM, 2013; Jaime Massardo, La formación del imaginario politico de Luis Emilio Recabarren, Santiago, LOM, 2008; Grez, op. cit., LOM 2011 y $465-503$; Barnard, Andrew, El Partido Comunista de Chile, 1922-1947, Santiago, Ariadna, 2017; Rolando Álvarez, "El Partido Comunista de Chile en la década de 1930: Entre "clase contra clase" y el Frente Popular", Pacarina del Sur, 8, 31, 2017; "La bolchevización del Partido Comunista de Chile: Antecedentes (1920-1927)", Patricio Herrera (Coordinador), El Comunismo en América Latina.

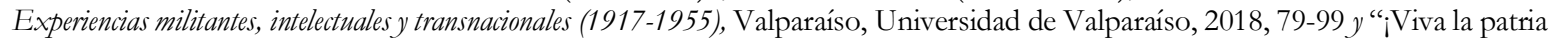
y la revolución! Partido Comunista y nacionalismo (1921-1926)", Revista de Historia Social y de las Mentalidades, 7, 2003, pp.25-44; Jorge Navarro, Revolucionarios y parlamentarios. Una cultura política del Partido Obrero Socialista, 1912-1922; Santiago, LOM, 2017; Juan Yañez, La OIT en América del Sur: El comunismo y los trabajadores chilenos (1922-1932), Santiago, Ediciones Universidad Alberto Hurtado, 2016.

${ }^{20}$ Hernán Venegas, "El Partido Comunista de Chile y sus políticas aliancistas: Del frente popular a la unión nacional antifascista, 1935-1943, Revista de Historia Social y de las Mentalidades, № 14, Santiago, 2010, pp. 85-111; Ximena Urtubia, Hegemonía y Cultura Política en el Partido Comunista de Chile. La transformación del militante tradicional (1924-1933), Santiago, Ariadna, 2017; Olga Ulianova, "El PC chileno durante la dictadura de Carlos Ibáñez (1927-1931): la primera clandestinidad y bolchevización estaliniana", Boletín de la Academia Chilena de la Historia, No111, Santiago, 2002, pp. 385-436; "República Socialista y soviets en Chile. Seguimiento y evaluación de una ocasión revolucionaria perdida”, Ulianova y Riquelme (Eds.), Chile en los archivos soviéticos, Tomo 2, pp. 173-206 y "Una crisis escuchada como la obertura de la revolución”, Ulianova y Riquelme (Eds.), Chile en los archivos soviético, Tomo 2, pp. 15-54. Marco González, "Comunismo chileno y cultura Frente Popular. Las representaciones de los comunistas chilenos a través de la revista Principios, 1935-1947”, Izquierdas, 11, Santiago, 2011, pp. 54-69; Vega Jara, Mariano, “¿Hidalguismo versus lafertismo? Crisis y disputa por la representación del comunismo en Chile, 1929-1933”, Ulianova, Loyola y Álvarez (Eds.), op. cit., 2012, pp. 97-114; Camilo Plaza, Soviets, cuartelazos y milicias obreras: los comunistas durante los doce días de la República Socialista, 1932, en, Ulianova, Loyola y Álvarez (Eds.), op. cit., 2012, pp. 171-193; Nicolás Acevedo, “La Voz del Campo, La Política Agraria del Partido Comunista durante el Frente Popular, 1936-1940”, Ulianova, Loyola y Álvarez (Eds.), op. cit., 2012, pp. 195-218.

${ }_{21}^{1}$ Moraga, op. cit., 109-156; Julio Jobet y Alejandro Chelen, op. cit., 1972; Paul Drake, op. cit., 1992; Ulianova, op. cit., 235-284; Reveco, op. cit., 19-134; Gabriel Salazar, Conversaciones con Carlos Altamirano. Memorias críticas. Santiago, Debate, 2011; Leopoldo Benavides, La formación de la izquierda chilena. Relaciones entre el Partido Comunista y el Partido Socialista, Santiago, FLACSO, 1988.

22Fabio Moraga, "El Congreso de Estudiantes Latinoamericanos de Santiago. Antiimperialismo e indoamericanismo en el movimiento estudiantil chileno (1935-1940)”, Historia Crítica, N 47, 2012, pp. 187-213. 
militancia con dinámicas e influjos extra nacionales ${ }^{23}$. No obstante, estos importantes aportes por parte de aquellos trabajos que incorporan la dimensión regional, transnacional o global al análisis de socialistas y comunistas, éstos se concentran mayoritariamente en la vinculación, por cierto, importante, del comunismo chileno con la III Internacional —o Komintern-, la cual como demuestra Ulianova para el periodo fundacional del PCCh y su primera etapa de inserción político e institucional tuvo una significativa injerencia.

Respecto a nuestro periodo específico de estudio sugerido, la gran mayoría de las investigaciones analizan a la izquierda chilena en una dinámica y espacio que no supera lo estrictamente nacional, por tanto, dejando al margen la dimensión latinoamericana o regional en la comprensión del recorrido histórico de ella. Como señalamos, llama la atención este aspecto, teniendo en cuenta el carácter internacionalista de la izquierda, así como el reconocimiento otorgado por la historiografía dedicada a estas temáticas respecto al peso de las dinámicas internacionales sobre comunistas y socialistas, ya sea desde el mundo soviético y su relación con los partidos comunistas latinoamericanos en el contexto de la guerra fría o por los vínculos de las distintas vertientes del socialismo chileno con las experiencias de los socialismos emergentes después de la Segunda Guerra mundial en Europa y las experiencias nacionalistas y populares en nuestro continente ${ }^{24}$.

La problemática o vacío anterior, se agudiza aún más, al dar una mirada rápida a la numerosa y diversa prensa partidaria, a los documentos oficiales (congresos, plenos, conferencias) o las memorias de importantes dirigentes comunistas y socialistas de la época, en donde aparecen y resaltan, nutridos y significativos vínculos, incidencia, influjos, solidaridades, redes militantes y discusiones sobre los diversos procesos políticos que se desenvolvían en forma paralela en nuestro continente.

Hasta ahora, estos aspectos de la trayectoria militante de la izquierda chilena, han sido tratados de forma aislada, monográfica y limitada al estudio de la recepción o "influencias externas" de procesos políticos sobre un solo partido. En este sentido, debemos resaltar los excelentes trabajos realizados por Joaquín Fernández al respecto, quién plantea igualmente la necesidad de incorporar una mirada más amplia a la comprensión de la izquierda chilena, emprendiendo con ello una importante tarea al estudiar los diagnósticos y las posiciones políticas levantadas por el PCCh respecto al Gobierno de la Revolución de Junio y el proceso político argentino entre 1943 y 1946, así como de la Dictadura de Gualberto Villarroel en Bolivia y el papel del Movimiento Nacionalista Revolucionario en ella, entre 1943 y 1946. Lo interesante de estos trabajos, es que identifica y analiza una serie de iniciativas políticas desarrolladas por el PCCh como resultado de la recepción y diagnóstico realizado por éstos respecto de dichos procesos, por tanto, demostrando la existencia de una permanente preocupación por lo regional, por los conflictos sociales y las dinámicas de los procesos latinoamericanos más significativos, al punto de llevar adelante lineamientos políticos y tareas concretas en nuestro país en función de dichos procesos o coyunturas abordadas y recepcionadas. En la misma línea de investigación, aborda el proceso de radicalización política del Partido Socialista Popular chileno entre los años 1948 y 1957, tomado como punto de partida la asimilación de concepciones y experiencias nacionalistas y socialistas de Latinoamérica.

Por su parte, el trabajo de Gabriel Salazar en "Conversaciones con Carlos Altamirano", aborda la trayectoria del socialismo chileno a partir de sus diversas y a ratos opuestas tendencias internas, sus contradicciones congénitas y su carácter pragmático, entre otros aspectos. Baja esta mirada, comprende la trayectoria partidaria a la luz de un contenido fundamentalmente democrático y fuertemente

$23 \mathrm{Al}$ respecto ver la amplísima bibliografía citada anteriormente.

${ }_{24} \mathrm{Al}$ respecto, ver la reflexión crítica y constructiva en los trabajos citados de Joaquín Fernández. También es destacable el estudio de Sebastián Rivera, quien da cuenta del trabajo político realizado por exiliados comunistas chilenos en México y Guatemala en el contexto de la Ley Maldita y la Guerra Fría, resaltando importantes vinculaciones y redes políticas de los comunistas chilenos a partir de una militancia transnacional. Al respecto ver, Sebastián Rivera, "El otro exilio chileno en México y Guatemala, 1948-1951. Militancia transnacional en los orígenes de la guerra fría”, HISTORIA N 50, vol. I, Santiago, 2017, pp. 209-240. 
influenciado con los procesos reformistas de América Latina desde los años 30 al 50, así como los revolucionarios de los años 60 y 70 del siglo pasado ${ }^{25}$.

Respecto a la segunda periodificación y nudo de estudios sobre la izquierda chilena, en la cual se inscribe la propuesta investigativa, 1952-1970, encontramos una cantidad significativa de estudios sobre diversas temáticas y actores. Tanto la historia social como la nueva historia política han contribuido notablemente a partir de sus enfoques y preocupaciones, a la ampliación del conocimiento y comprensión de las trayectorias socialistas y comunistas durante este periodo. Resaltan en este sentido, las diversas disputas partidarias internas, la configuración de alianzas electorales y programáticas, la política de masas y unidad, la vinculación de comunistas y socialistas con diversos actores sociales componentes del vasto movimiento popular chileno y sus luchas; los debates teóricos y partidarios en torno a los grandes "problemas nacionales" y el carácter de la revolución "chilena", así como los procesos políticos "internos" que dieron sentido, configuraron y tensionaron la construcción del proyecto estratégico de la izquierda chilena ${ }^{26}$

En cuanto al proceso de construcción programática y estratégico de la izquierda chilena, salvo los textos citados de Faundez, Casals, Moulian y Corvalan, son escasos los trabajos que centran su preocupación en ello. En gran parte de estos estudios, se profundiza en torno a las dinámicas y discusiones particulares de las organizaciones de izquierda y en las características del desarrollo político nacional (elecciones, nuevas alternativas-construcción de proyecto y alianzas), así como en las cualidades de la izquierda chilena que permitieron leer y aprovechar las condiciones favorables para el desarrollo de su proyecto estratégico.

Respecto a la vinculación de los procesos políticos latinoamericanos y la izquierda chilena, llama la atención que, salvo el caso de Luis Ortega para el socialismo y de Eugenia Palieraki para el MIR ${ }^{27}$

25 Salazar, op. cit., 2011.

${ }^{26}$ La bibliografía sobre estas temáticas es abundante, por lo que señalaremos las más pertinentes y distintiva de ella: Marcelo Casals, El alba de una revolución. La izquierda y el proceso de construcción estratégica de la "vía chilena al socialismo", 1956-1970, Santiago, LOM, 2010; Julio Faúndez, Izquierdas y democracia en Chile, 1932-1973, Santiago, BAT Ediciones, 1992; Benavides, op. cit. 1988, Tomás Moulian, "Líneas estratégicas de la izquierda: "frentismo", populismo, antireformismo. 1933-1973", Santiago, Flacso, 1982; Carmelo Furci, El Partido Comunista de Chile y la vía al socialismo, Santiago, Ariadna, 2008; Drake, op. cit. 1992; Isabel Torres, La crisis del sistema democrático: las elecciones presidenciales y los proyectos políticos excluyentes. Chile, 1958-1970, Santiago, DIBAM-Editorial Universitaria, 2014; Luis Corvalán, Del anticapitalismo al neoliberalismo: Izquierda, centro y derecha en la lucha entre los proyectos globales, 1950-2000, Santiago, Sudamericana, 2002; Hernán Venegas, "El Partido Comunista de Chile: Antecedentes ideológicos de su estrategia hacia la Unidad Popular (1961-1970)", Revista de Historia Social y de las Mentalidades, № 7, Santiago, 2003, pp. 45-69; Pollack, Benny y Hernán Rosenkraz, Revolutionary Socialdemocracy: The Chilean Socialist Party. Londres, Pinter, 1986; Camilo Fernández y Pablo Garrido, "Progresistas y revolucionarios: el Frente de Acción Popular y la Vía Chilena al Socialismo, 1956-1967”, Irquierdas 31, Santiago, 2016, pp. 71-101; Luis Ortega, "Del Frente de Trabajadores al Congreso de Chillán. Los Socialistas de Chile entre 1956 y 1967", Revista Electrónica Palimpsesto, 1, 2003 y "La radicalización de los socialistas de Chile en la Década de 1960", Universum, 23. 2, 2008, 152-164; Jorge Arrate y Eduardo Rojas, Memoria de la Irquierda Chilena (tomo 2), Santiago, Vergara editor, 2003; Joaquín Fernández: "Populismo, democracia y marxismo: el debate de la izquierda chilena y la candidatura presidencial de Salvador Allende en 1952". Finis Terrae, Revista de Humanidades 1, 2013, pp. 41-58 y "Allende, el allendismo y los partidos: El Frente de Acción Popular ante las elecciones presidenciales de 1958”, Izquierdas, N²3, Santiago, 2015, pp. 157190; Pablo Garrido, "La contribución teórica de la Unidad Popular. Revolución y democracia en el programa de la Vía Chilena al Socialismo", Izquierdas, N²1, Santiago, 2014, pp. 128-151; Paula Vidal, "La categoría de Igualdad en el Partido Comunista de Chile en los años 60”, Irquierdas, N 9, Santiago, 2011, pp. 67-78; Ignacio Walker, op. cit. pp.117-171; Tomás Moulian, Evolución Histórica de la izquierda chilena: Influencia del Marxismo, FLACSO, Documento de trabajo 139, Santiago, 1982; Pablo Garrido, "Un Frente de Trabajadores comandado por la clase obrera: El Partido Socialista Popular y las definiciones iniciales en torno a la política del Frente de Trabajadores, 1946 - 1957”, Izquierdas, 35, Santiago, 2017, pp. 233-259.

27 Eugenia Palieraki, La revolución ya viene. El MIR chileno en los años sesenta, Santiago de Chile, LOM. 2014; Luis Ortega, op. cit., 152-164. Para el caso del PCCh, existe el estudio de Alexia Massholder, quien reconstruye la recepción de la Revolución Cubana por parte del Partido Comunista de Chile y el de Uruguay. Establece además la importancia del debate abierto a partir del triunfo cubano respecto a las características de la revolución y las vías para lograrla. En cuanto al PCCh, el acercamiento al tema de la recepción es durante los primeros años de la revolución. Comparativamente con el caso uruguayo, hay menos fuentes y profundidad en el análisis. Del estudio se desprende que el PCCh no tuvo mayor preocupación por el proceso cubano, tanto por la poca participación de los comunistas cubanos en la revolución, como por el peso dado a la guerra de guerrillas en cuan to a formas de lucha y la distancia de los comunistas chilenos respecto de ella. Según la autora, existe una valoración del PCCh 
(quienes matizan el impacto de la revolución cubana en los procesos de radicalización política chilena), la gran mayoría de los trabajos sentencien de forma casi absoluta, la influencia o tensionamiento ejercido por la revolución cubana en la trayectoria de la izquierda chilena, en su radicalización política, sin calibrar o dimensionar su impacto y significado en la trayectoria de la izquierda en su globalidad y sobre todo, en el despliegue o materialización de su programa político de transformaciones y su proyecto estratégico.

Misma situación (ausencia de estudios) podemos observar respecto al golpe de estado que afectó a Brasil en 1964, su impacto y recepción política en Chile, el cual, entre otros aspectos, abrió un nuevo ciclo político de dictaduras para la región, resituando además, los debates en torno a las vías de la revolución, el carácter del Estado y la existencia y papel de la burguesía latinoamericana en los procesos de cambio estructural28. Así, los estudios que abordan la izquierda chilena en una perspectiva internacional, lo hacen desde lo institucional, identificando y destacando el impacto o los "factores externos" y no la vinculación y recepción, significación y apropiación de ideas, procesos, aprendizajes, solidaridades, entre otros aspectos ${ }^{29}$.

Aunque escapan temporalmente a la problemática de estudio propuesta, quisiéramos destacar la producción historiográfica generada en torno al periodo abierto desde la derrota de la Unidad Popular hasta los inicios de la transición democrática. Al respecto, solamente daremos cuenta de aquellos estudios que han tratado e inscrito la historia de la izquierda chilena como parte de un campo y una experiencia extranacional y global, incluyendo recepción de ideas y proyectos políticos. Destacan en este sentido, los trabajos que dan cuenta de los giros y las renovaciones políticas, los debates intelectuales, la recepción de procesos revolucionarios, la fragmentación política partidaria y de los grandes bloques políticos de la izquierda; las discusiones-tensiones entre la militancia del interior y el exterior; las experiencias y aprendizajes de los exilios, los cambios de estrategias para enfrentar la dictadura, entre otros aspectos ${ }^{30}$.

respecto del proceso cubano en cuanto a las trasformaciones llevadas adelante, pero también tendió a reforzar su estrategia de vía pacífica a partir del debate abierto por los cubanos. Teniendo en cuenta la revisión de fuentes relativas al comunismo chileno desarrolladas en el marco de nuestra investigación, es posible sostener que el proceso cubano es seguido tempranamente por el comunismo chileno, tanto el diario El Siglo (incluso, antes del triunfo del Movimiento 26 de julio), así como artículos publicados en su principal revista teórica-política (Principios) y las numerosas intervenciones de dirigentes comunistas en el parlamento y la prensa chilena evidencian lo que estamos señalando. De ahí la importancia de estudiar la recepción de la revolución cubana en el comunismo chileno en un periodo más largo, a objeto de calibrar su impacto en la formulación de su proyecto programático y estratégico en torno a la vía chilena al socialismo. Al respecto ver, Alexia Massholder, "La recepción de la Revolución Cubana en los Partidos Comunistas de América Latina”, Irquierdas, № 42, Santiago, 2018, pp.122-136.

28 La gran mayoría de los trabajos que vinculan el proceso brasileño con Chile, abordan la relación de militantes brasileños exiliados en Chile y su incorporación, en algunos casos, a las organizaciones políticas de la izquierda chilena. Al respecto ver: Ivette Lozoya, "Theotonio Dos Santos, un intelectual revolucionario", Irquierdas, Santiago, 25, 2015, pp. 258-275; "Pensar la Revolución: Pensamiento Latinoamericano e intelectuales en el MIR chileno. 1965-1973. Propuesta teórico metodológica para su estudio desde la Historia Intelectual y la Historia de la Violencia”, Revista de Humanidades, 27, Santiago, 2013, pp. 173-197; Claudia Wasserman, "Transição ao socialismo e transição democrática: exilados brasileiros no Chile”, História Unisinos, $N^{\circ} 16,1$, Janeiro, 2012, pp. 82-92; Mateus Filippa Meireles, Origens da Teoria Marxista da Dependência: o Centro de Estudos Socioeconômicos (CESO) da Universidade do Chile e a práxis de Ruy Mauro Marini, Vânia Bambirra e Theotonio dos Santos (1966-1973), Universidade Federal do Rio Grande do Sul, Departamento de História, Trabalho de Conclusão requisito parcial para a obtenção do grau de Licenciado em História, 2014; Alberto Aggio, "Brasileiros de esquerda no Chile de Allende: protagonismos, divergências, lições”, Os 70 anos do Estado Novo de Vargas, Política Democrática Revista de Política e Cultura, N²9, Brasília, 2007, pp. 114-122; Teresa Schneider, "O Exílio e as Transformações de Repertórios de Ação Coletiva: A Esquerda Brasileira no Chile e na França (1968-1978)”, DADOS - Revista de Ciências Sociais, no 1, vol. 60, Rio de Janeiro, 2017, pp. 239279.

${ }_{29}$ María Soledad Gómez, "Factores nacionales e internacionales de la política interna del Partido Comunista en Chile (1922-1952)”, Varas, op. cit., pp.75-120; Boris Yopo, "Las relaciones internacionales del Partido Comunista”, Varas, op. cit., pp. 247-260.

30 Riquelme, op. cit., 2009; Rolando Álvarez, Arriba los pobres el mundo. Cultura e identidad política del Partido Comunista de Chile entre democracia y dictadura. 1965-1990, Santiago, LOM, 2011; Cristina Moyano, "Diálogos entre el exilio y el interior. Reflexiones en torno a la circulación de ideas en el proceso de renovación socialista, 1973-1990”, Izquierdas, N 9, Santiago, 2011, pp.31-46; Julio Pinto, “¿Y la historia les dio la razón? El MIR en dictadura, 1973-1981”, Verónica Valdivia, Rolando Álvarez y Julio Pinto, Su revolución contra nuestra revolución. Izquierdas y derechas en el Chile de Pinochet (1973-1981), Santiago, LOM, 2006; pp. 153-205; Viviana Bravo, ¡Con la razón y la fuerza, venceremos! La Rebelión Popular y la Subjetividad Comunista en los '80. Santiago, Ariadna, 2010; Claudio 
En general, podemos concluir que en gran parte de los estudios sobre la izquierda chilena ha primado la mirada local para dar cuenta de su trayectoria histórica-política, tanto de sus estructuras, experiencias, militancias y formulación de proyecto. A pesar de los enormes avances en cuanto a diversidad de temáticas y aportes de la Nueva Historia Política, con novedosas metodologías y marcos teóricos, existe un notable predominio de lo local por sobre lo transnacional y regional en nuestro caso. Por tanto, lo nacional y las particularidades del sistema político siguen explicando en gran medida la trayectoria de la izquierda, reforzando en algunos casos, las tesis del particularismo chileno, presentándonos la construcción estratégica del proyecto de la izquierda chilena durante los cincuenta y sesenta del siglo pasado, como creación exclusiva o propia, la vía chilena al socialismo como hija legítima de la izquierda chilena, producto de la unidad PS-PC y las características y desarrollo del régimen político chileno ${ }^{31}$.

Teniendo en cuenta lo anterior, proponemos aportar a los estudios sobre la etapa de construcción del proyecto político estratégico de la izquierda chilena, desde una comprensión transnacional. Esto no significa poner en cuestión la legitimidad de esta construcción por parte de la izquierda chilena, sino ampliar el escenario de gestación y semblanzas que rodearon el parto de la vía chilena. En definitiva, la apuesta busca complementar una parte de la historia de la izquierda chilena a partir de la historia política latinoamericana y la historia trasnacional.

\section{III}

Bajo este marco de referencias teóricas y metodológicas, volvemos a la problemática inicial, ¿es la vía chilena al socialismo resultado particular de las dinámicas y características estructurales de nuestra sociedad y, por tanto, construcción política exclusiva de la izquierda chilena? Si consideramos algunos de los planteamientos de Salvador Allende, propulsor y pilar fundamental de la vía chilena al socialismo, diríamos que sí. Por ejemplo, cuando señala que, sin vanidad alguna, puede establecerse que Chile "es uno de los países de este continente que ha alcanzado un mayor desarrollo en la evolución democráticoburguesa. Chile se ha caracterizado por tener una estructura institucional que ha perdurado, con muy leves interrupciones, durante largos años. El Congreso de Chile (del cual formé parte durante veintisiete años, y donde ocupé el cargo de presidente del Senado) tiene ciento sesenta años de vida ininterrumpida". Chile es, sentencia Allende, "uno de los tres países del mundo que tienen Parlamentos que sobrepasan los 150 años". Lo que demostraría, según éste, "cierta estabilidad en el desarrollo de nuestras instituciones...", alcanzando con ello, "más que otros países, la posibilidad de una convivencia política amplia". En base a lo anterior, concluye Allende, "queremos, dentro de nuestro modelo político, a partir del pluralismo, la democracia y la libertad, utilizar la institucionalidad burguesa, para hacer posible los cambios que este país reclama y necesita, en el campo político, en el campo económico y en el campo social, para llegar al socialismo. En el caso de Chile, es posible el uso de la institucionalidad, porque es amplia y abierta para estos cambios" 32 .

Por otro lado, si consideramos las concepciones, diagnósticos y apuestas de una parte significativa de partidos que se articularon en torno al largo camino de la vía chilena al socialismo, así como una gama diversa de investigaciones sobre la trayectoria de la izquierda chilena desde la década de los cincuenta hasta el golpe de estado de 1973, respecto al carácter del proceso político y de las

Pérez, "La Tarea Militar del Partido Comunista de Chile: ¿Continuidad o ruptura de la Política Militar del comunismo chileno?”, Izquierdas, N²9, Santiago, 2016, pp. 49-82.

$31 \mathrm{Al}$ respecto, ver: "En Chile, las instituciones de la democracia formal se han caracterizado por un desarrollo consistente y real que ha permitido la coexistencia de fuerzas políticas antagónicas por naturaleza, sin que la lucha entre ellas haya derivado en la imposición violenta de unas sobre otras”. Claude Heller, Política de unidad en la irquierda chilena (1956-1970), Ciudad de México, El Colegio de México, 1973, p. 1.

32 La vía chilena al socialismo. Exposición inaugural del presidente de la República de Chile, Dr. Salvador Allende. Seminario realizado en 1972. Siglo XXI Editores, Santiago 1973, p. 5. 
condiciones nacionales para la viabilidad de este proyecto, también sería posible sostener que la formulación y despliegue de la vía chilena al socialismo es un producto naciente de la propia experiencia y reflexión nacional de los partidos.

No obstante, si nos preguntamos respecto a la posibilidad de explicar el proceso de construcción de un programa político y proyecto estratégico por parte de los dos grandes partidos de la izquierda chilena, socialista y comunista, solamente a partir de las condiciones y cualidades de los diversos actores e instituciones políticas nacionales, dejando de lado las concepciones latinoamericanistas e internacionalistas, la respuesta sería negativa. La diferencia anterior es fundamental a nuestro parecer, ya que se asimila y limita la "vía chilena al socialismo" solamente al problema de las formas y las vías de la revolución o la conquista del socialismo. Es decir, se resalta el marco legal e institucional de su apuesta como el elemento particular y propio de la izquierda chilena a nivel global.

Teniendo en cuenta las concepciones internacionalistas y latinoamericanistas que definen a comunistas y socialistas respectivamente, estimamos necesario ampliar el marco de preguntas y problemas a resolver en el ámbito historiográfico. Consideramos necesario, incluir en el estudio de la construcción del proyecto político de la izquierda chilena, un enfoque transnacional de lo político, entendido como un elemento central en la configuración política y programática de la izquierda chilena, que permita identificar y calibrar los vínculos y los influjos latinoamericanos en el recorrido político de la construcción de la vía chilena.

En definitiva, interrogándola sobre debates y problemas comunes que atravesaron a todo el continente y por tanto a toda la izquierda latinoamericana. Que incluya vinculación, redes, recepción, balances, apropiación y resignificación realizada por la izquierda chilena respecto de dinámicas y procesos políticos de nuestro continente, que contuvieron al menos, elementos de análisis y diagnósticos similares respecto a la realidad política económica nacional, así como propuestas relativas a la democratización de la sociedad, el termino del latifundio y los monopolios.

Considerando lo anterior, sostenemos que la construcción del proyecto político estratégico desarrollado por socialistas y comunistas durante la década de los cincuenta y sesenta del siglo pasado, contiene en su trayectoria y configuración, importantes significaciones y afluentes provenientes de conflictos y procesos políticos latinoamericanos que se desencadenaban simultáneamente en nuestro continente. Sobre todo, aquellos en los cuales se compartían diagnósticos y apuestas políticas genéricas, de corto y mediano plazo. De esta manera, es posible sostener igualmente, que el particularismo chileno o lo inédito de la experiencia chilena no operó en los aspectos programáticos y de proyecto histórico, ya que experiencias simultáneas a la izquierda chilena en relación a procesos de modernización, democratización, luchas antilatifundistas, antioligarquicas y antiimperialistas se habían y continuaban presentado en el continente en forma paralela, generando entre otras cosas, importantes debates en la izquierda latinoamericana, al cual por concepciones políticas y vínculos internacionales, socialistas y comunistas no estaban ajenos.

Bajo este marco, también afirmamos que los debates nacientes de las experiencias y dinámicas políticas latinoamericanas, de los aciertos y derrotas de las izquierdas en el continente, así como los nuevos planteamientos teóricos, programáticos y tácticos surgidos de dichas discusiones y balances; de las articulaciones políticas y sociales regionales que se desarrollaron a lo largo del continente y la recepción y significación realizada de estos procesos por parte de la izquierda chilena, se transformaron en importantes insumos políticos coyunturales, los cuales alimentaron y tensionaron la discusión de largo alcance en torno políticas de alianzas y de clases, aspectos programáticos y estratégicos, así como del carácter de la revolución chilena.

De esta manera, el vasto y a veces contradictorio abanico de relaciones políticas, sociales, diplomáticas, culturales e intelectuales llevadas oficialmente por las estructuras partidarias y en muchos casos informalmente por sus militantes, con otras expresiones políticas y sociales de las izquierdas latinoamericana, así como las concepciones preconcebidas entre socialistas y comunistas respecto a 
centralidad de actores-clases y articulación política a nivel internacional, condicionó la recepción inicial y la significación de los procesos políticos latinoamericanos.

En cuanto a los procesos seleccionados para el análisis de la recepción por parte de la izquierda chilena, hemos privilegiado aquellos en los cuales encontramos mayor evidencia respecto a relaciones partidarias formales y vinculaciones políticas militantes que traspasan la propia estructura formal de éstos, con abundante información y notoria identificación a través de la prensa y documentación partidaria, así como en las numerosas memorias militantes y discursos parlamentarios en los cuales se hace referencia a estos procesos en cuanto al significado político de las reformas económicas, políticas y sociales implementadas y al carácter de ellas ${ }^{33}$. Por último, hemos considerado el impacto regional de estas reformas y transformaciones y los subsecuentes debates generados entre las organizaciones de izquierda a nivel latinoamericano a partir de ellas ${ }^{34}$.

Estos procesos y experiencias de las izquierdas latinoamericanas, impactaron de manera desigual entre los partidos y la militancia chilena, generando una resignificación heterogénea de ellos, lo cual operó como un punto permanente de fricción entre comunistas y socialistas, sobre todo, respecto de discusiones en torno al rol de los diferentes actores políticos y sociales, las alianzas políticas, las formas de lucha, el carácter de la revolución y las vías para lograrla.

Son precisamente los aspectos señalados más arriba los que nos interesa problematizar, indagando y analizando la recepción y significación de estos procesos políticos latinoamericanos por parte de la izquierda chilena, entre 1952 y 1970 . Bajo este gran objetivo, estimamos necesario calibrar la recepción y significado que tuvo, entre socialistas y comunistas, la Revolución Boliviana (1952), el proceso de democratización guatemalteco y el derrocamiento de Jacobo Árbenz en 1954. De igual forma, comparar el significado que tuvo para el PCCh y el Partido Socialista de Chile (PSCh) el triunfo y trayectoria de la Revolución Cubana durante los años sesenta; así como las discusiones y balances emanados entre socialistas y comunistas respecto al gobierno y derrocamiento de Joao Goulart en Brasil (1964) y sus proyecciones en el FRAP en cuanto a formas de lucha, caracterización del Estado y de las burguesías nacionales y latinoamericanas.

Creemos importante evaluar el impacto de la revolución cubana y el golpe de Estado en Brasil en el surgimiento de la nueva izquierda chilena, particularmente en el Movimiento de Izquierda Revolucionaria, MIR, así como también en tensionamientos y debates producidos al interior de la Democracia Cristiana y que dieron como resultado el nacimiento del Movimiento de Acción Popular

\footnotetext{
${ }^{33}$ Entendemos, existen otros procesos políticos locales que traspasaron las fronteras nacionales y fueron objeto de seguimiento y debate, tanto por comunistas como por socialistas. Por ejemplo, el gobierno de Juan Bosh y el Golpe de Estado en República Dominicana en 1963; el Gobierno y proceso de democratización de Rómulo Betancourt en Venezuela y la experiencia del reformismo militar con Juan Velasco Alvarado en Perú. No obstante, consideramos que la mayor densidad de referencias programáticas y proyectuales identificadas a través de la revisión de fuentes partidarias y debates al interior de la propia izquierda chilena, es a partir de los procesos seleccionados para esta propuesta investigativa.

$34 \mathrm{Al}$ respecto, el discurso de Salvador Allende en homenaje a la Revolución Cubana en julio de 1960, es demostrativo de lo que estamos señalando: "Rendimos homenaje a las milicias inmoladas hace siete años en el asalto al cuartel Moncada y lo hacemos expresando que los sectores populares de Chile, la inmensa mayoría del pueblo, siente, comparte y vive los ideales de la revolución cubana. Tal hecho no puede ser extraño para nadie porque, en la conciencia del pueblo chileno, existe la inmensa y profunda convicción de que América Latina está viviendo uno de los minutos más trascendentales de su historia; que las revoluciones mexicana y boliviana señalaron ya una etapa, y que la cubana marca con caracteres imborrables un proceso de superación, al dar sólidos pasos hacia la plena independencia económica y señalar, con su lucha, el camino que han de seguir los pueblos latinoamericanos para afianzar y acelerar la evolución política, económica y social que los lleve a ser auténtica y definitivamente libres...La revolución latinoamericana, con características distintas en su táctica y estrategia -repito- en cada uno de nuestros pueblos, tendrá como fondo indiscutible una lucha emancipadora en lo económico, una frontal batalla contra el imperialismo y un combate decisivo contra el régimen feudal de explotación de la tierra y del trabajador del agro. Ayer era Guatemala el polvorín comunista que ponía en peligro la hermandad americana. Hoy es Cuba...Como siempre, la raída bandera del anticomunismo se esgrime para atentar en contra de la soberanía de los pueblos: ayer, contra Guatemala; hoy, contra Cuba”. Extractos del discurso de Salvador Allende en el Senado de la República de Chile, el 27 de julio de 1960.
} 
Unitario, MAPU. Del mismo modo, nos interesa identificar formas, espacios, actores y dinámicas de recepción que se desarrollaron en la izquierda chilena respecto a los procesos políticos señalados. Por último, dimensionar el impacto e incidencia política de estos procesos en cuanto a ejes programáticos, aspectos teóricos, definición de alianzas y vías de la revolución propuestas por la izquierda en torno a la "vía chilena al socialismo".

Como señalamos, particular importancia para nuestra problemática de estudio, tienen las aportaciones de la Nueva Historia Política y la historia de las izquierdas, las cuales desde una perspectiva trasnacional nos permiten vincular lo local, nacional, regional y lo global como un todo posible de analizar y comprender. Lo anterior, teniendo en cuenta la amplitud de redes desarrolladas por el socialismo chileno a propósito de sus múltiples tendencias y liderazgos; las relaciones formales construidas por el comunismo chileno con sus pares latinoamericanos, así como su estrecha relación con el Movimiento Comunista Internacional; por último, la gran incidencia que tenían ambos partidos en el movimiento obrero, la intelectualidad y el espectro artístico cultural, expresiones todas con importantes vínculos, sensibilidades y relaciones a nivel latinoamericano.

Esta propuesta, tiene como centro de su investigación el problema de la recepción de procesos políticos, su significación e impacto en actores políticos que se encuentran en pleno proceso de construcción de su proyecto político-programático y estratégico. Particularmente, aquel experimentado por la izquierda chilena a partir de la ilegalidad del Partido Comunista de Chile (1948), la reunificación del socialismo chileno, la emergencia de los referentes electorales y programáticos como el Frente de Acción Popular (1956) y la Unidad Popular (1969) hasta el triunfo electoral de Salvador Allende en 1970. Nos proponemos identificar la recepción de los procesos políticos latinoamericanos en la izquierda chilena desde una perspectiva diacrónica, así, estimamos posible reconocer las formas de recepción, dimensionar el impacto particular de cada proceso político e identificar los niveles de incidencia política en la trayectoria de la izquierda chilena. Finalmente, esta apuesta investigativa, nos permitirá identificar y comparar los procesos latinoamericanos más significativos para la izquierda chilena y su aporte en la construcción de su proyecto estratégico. Considerando lo anterior, estimamos pertinente observar estos procesos a partir de las siguientes categorías de análisis: recepción, actores y conflicto político.

Estudios sobre las memorias militantes escritas por altos dirigentes de la izquierda chilena, nos muestran que los procesos políticos más significativos experimentados en nuestro continente, desde mediados del siglo XX, tienen una gran caja de resonancia y recepción por parte estas colectividades y entre su militancia. Se despliegan en distintos escenarios y dinámicas políticas, y son recepcionados también de forma diversa por parte de actores políticos agrupados orgánicamente en torno al Partido Comunista de Chile y las diversas tendencias socialistas que operaron en Chile hasta la unificación del socialismo en 1957. Bajo este marco, entendemos como actores políticos aquellas agrupaciones o sujetos articulados políticamente en torno a estos dos grandes partidos de la izquierda chilena centrales en la construcción de "la vía chilena al socialismo", así como también aquellas organizaciones de izquierda que se constituyeron durante el periodo en estudio, producto de su incidencia en el escenario político nacional y en el proceso de tensionamiento y construcción del proyecto estratégico de la izquierda chilena, como lo fueron el MIR (1965) y el MAPU (1969) respectivamente.

Estos diversos actores políticos nacionales, el grueso de ellos constituidos ideológicamente en torno al marxismo-leninismo, con una fuerte tradición obrerista y un gran peso político entre los trabajadores organizados y las diversas expresiones del movimiento popular chileno, los intelectuales y el campo de la cultura, se vieron a nuestro entender sensibilizados, vinculados y tensionados permanentemente por las diversas coyunturas políticas latinoamericanas (particularmente aquellas que hemos mencionado más arriba) y en las cuales podemos observar importantes y diversos niveles de vinculación entre los actores políticos nacionales (PCCh y PSCh mayoritariamente) y éstas.

El conflicto político, nos permite entender los cambios operados en contexto de crisis, las rearticulaciones políticas y sociales, la emergencia de alianzas y actores que comparten orientaciones, lógicas de movilización y protesta, incluso diversos grados de organización y unidad, facilitando las 
dinámicas colectivas y el actuar común en relación a expectativas de mejora o cambios coyunturales, programáticos y en algunos casos la creación de un contraproyecto político y social ${ }^{35}$. Por tanto, concebimos el conflicto político y la construcción de proyectos políticos estratégicos a partir de la lucha y confrontación política o de las diferencias abiertas entre distintos grupos opuestos, correspondientes a la valoración realizada de la situación y las expectativas de cambio de cada grupo o sector.

Por último, el conflicto político nos permite identificar los distintos actores que interactúan en dicho proceso, los escenarios principales de éste; acercarse a las principales ideas, valores y objetivos que portan los actores en conflicto, en el caso particular de nuestro estudio, la izquierda chilena agrupada en torno a la unidad socialista comunista y la construcción de su proyecto. De la misma manera y en un plano social, el conflicto político nos acerca a las motivaciones y expectativas; la búsqueda de nuevos elementos teóricos, concepciones o ideologías, aspectos y elementos que posibilitan el reconocerse como actor político articulado a un proyecto, con solidaridades y lealtades en su cuerpo ${ }^{36}$.

En cuanto a la recepción, la entendemos como un proceso diverso y epocal de apropiación crítica de acontecimientos y experiencias vivas, ideas y procesos políticos e imaginarios culturales, a través de mediaciones, circulación, solidaridades y concepciones preconcebidas, las cuales generan en el sujeto receptor, simpatías, distanciamientos, diversas valoraciones, adscripciones y consecuencias políticas, ideológicas y teóricas, así como prácticas ${ }^{37}$.

Bajo este marco, creemos posible a partir de la recepción trasnacional de experiencias e ideas, identificar y calibrar la resignificación de dichos procesos por parte de la izquierda chilena, los imaginarios previos y las mutaciones generadas por la recepción y significación. En esta propuesta de investigación, preguntarnos por las características de una experiencia política triunfante o derrotada, implica una reevaluación de la propia práctica política, la necesidad de nuevos fundamentos para conservar las concepciones existentes o simplemente la remoción de presupuestos políticos o teóricos y, en algunos casos la incorporación de nuevos elementos a la configuración del sujeto político receptor. Comprender la historia de la izquierda chilena a partir de la recepción trasnacional en un dialogo permanente entre lo local y lo global, nos invita a preguntarnos cómo se produce la recepción de experiencias e ideas, cómo se despliegan los procesos políticos latinoamericanos, quién o quiénes realizan el análisis y cómo se reproduce dicha resignificación. Por tanto, la concepción del receptor en esta apuesta metodológica, es comprendido como un sujeto político activo y creativo, en búsqueda de afluentes teóricos, afirmaciones y experiencias posibles.

\section{Bibliografía}

Alberto Aggio, "Brasileiros de esquerda no Chile de Allende: protagonismos, divergências, lições", Os 70 anos do Estado Novo de Vargas, Politica Democrática Revista de Política e Cultura, N²9, Brasilia, 2007.

Alejandro Chelén, Trayectoria del socialismo, Buenos Aires, Austral, 1968.

35 Pedro Cadarso, Fundamentos Teóricos del Conflicto Social. Madrid, Siglo XXI, 2001.

36 Idem.

${ }^{37}$ Federico Duarte, "Imágenes de esperanza: la apropiación del ejemplo de la Revolución Cubana por los grupos de la izquierda brasileña en los años sesenta", Irquierdas, $\mathrm{N}^{\circ}$ 4, 3, Santiago, 2009, pp. 1-14; Horacio Tarcus, "El marxismo en América Latina y la problemática de la recepción transnacional de las ideas", Temas de nuestra América, N 54, Ciudad de México, 2013, pp. 35-86; "La historia intelectual y la problemática de la recepción”. Introducción del libro Marx en la Argentina. Sus primeros lectores obreros, intelectuales y científicos (1871-1910), Buenos Aires, Siglo XXI, 2007, pp. 21-59; Eduardo Devés, "El traspaso del pensamiento de América latina a África a través de los intelectuales caribeños", História UNISINOS, Vol. 9, N 3, Porto Alegre, 2005, pp. 190197; Roberto Pittaluga, "De profetas a demonios: Recepciones anarquistas de la Revolución Rusa (Argentina 1917-1924)", Sociohistórica, 11-12, 2002, 69-98; Soviets en Buenos Aires. La izquierda de la Argentina ante la revolución en Rusia, Buenos Aires, Prometeo Libros, 2015. 
Alexia Massholder, "La recepción de la Revolución Cubana en los Partidos Comunistas de América Latina”, Izquierdas, N 42, Santiago, 2018.

Alfredo Riquelme, "La Guerra Fría en Chile: los intrincados nexos entre lo nacional y lo global", Alfredo Riquelme y Tanya Harmer, Chile y la guerra fría global, RIL Editores-Instituto de Historia UC, 2014.

---Un rojo atardecer. El comunismo chileno entre dictadura y democracia. DIBAM. Santiago, 2009.

Barnard, Andrew, El Partido Comunista de Chile, 1922-1947, Santiago, Ariadna, 2017.

Barry Carr, "Escribiendo la historia de los comunismos en las Américas: Retos y nuevas oportunidades", Patricio Herrera (Coordinador), El Comunismo en América Latina. Experiencias militantes, intelectuales y transnacionales (1917-1955), Valparaíso, Universidad de Valparaíso, 2018.

Boris Yopo, "Las relaciones internacionales del Partido Comunista", Augusto Varas, Alfredo Riquelme y Marcelo Casals (ed), Santiago, Catalonia, 2010.

Camilo Fernández y Pablo Garrido, "Progresistas y revolucionarios: el Frente de Acción Popular y la Vía Chilena al Socialismo, 1956-1967”, Izquierdas 31, Santiago, 2016.

Camilo Plaza, "S Soviets, cuartelazos y milicias obreras: los comunistas durante los doce días de la República Socialista, 1932", Olga Ulianova; Rolando Álvarez y Manuel Loyola (ed), 1912-2012 El Siglo de los Comunistas, Santiago, IDEA-USACH, 2012.

Carmelo Furci, El Partido Comunista de Chile y la vía al socialismo, Santiago, Ariadna, 2008.

Carmen de la Guardia y Juan Pan-Montojo, "Reflexiones sobre la historia transnacional”, Studia Histórica, Historia Contemporánea, 16, Salamanca, 1998.

Casals, Marcelo, El alba de una revolución. La izquierda y el proceso de construcción estratégica de la "vía chilena al socialismo". 1956-1970, Santiago, LOM, 2010.

Claude Heller, Politica de unidad en la izquierda chilena (1956-1970), Ciudad de México, El Colegio de México, 1973.

Claudia Wasserman, "Transição ao socialismo e transição democrática: exilados brasileiros no Chile", História Unisinos, $N^{\circ}$ 16, 1, 2012.

Claudio Pérez, "La Tarea Militar del Partido Comunista de Chile: ¿Continuidad o ruptura de la Política Militar del comunismo chileno?", Izquierdas, N²9, Santiago, 2016.

Conrad, Sebastían. Historia Global. Una nueva visión para el mundo actual, Barcelona, Crítica, 2017.

Cristina Moyano, "Diálogos entre el exilio y el interior. Reflexiones en torno a la circulación de ideas en el proceso de renovación socialista, 1973-1990”, Izquierdas, Nº 9, Santiago, 2011.

---"La historia política en el bicentenario: entre la historia del presente y la historia conceptual. Reflexiones sobre la nueva historia política", Revista de Historia Social y de las Mentalidades, № 1, 15, 2011. 
Danny Monsálvez, "La historia reciente en Chile: un balance desde la nueva historia política historia", 396 No 1, 6, Viña del Mar, 2016.

---"La dictadura militar de Augusto Pinochet como Nueva Historia Política: Perspectiva historiográfica y algunos temas para su indagación”, Revista Austral de Ciencias Sociales, 23, Valdivia, 2012.

Eduardo Devés, "El traspaso del pensamiento de América latina a África a través de los intelectuales caribeños", História UNISINOS, Vol. 9, N. 3, Porto Alegre, 2005.

Eduardo Zimmermann, "Estudio Introductorio. Una nota sobre nuevos enfoques de historia global y transnacional", Estudios Sociales del Estado, N 5, 3, Buenos Aires, 2017.

Eugenia Palieraki, La revolución ya viene. El MIR chileno en los años sesenta, Santiago de Chile, LOM. 2014.

Fabio Moraga, "El Congreso de Estudiantes Latinoamericanos de Santiago. Antiimperialismo e indoamericanismo en el movimiento estudiantil chileno (1935-1940)", Historia Crítica, № 47, 2012.

---“¿Un partido indoamericanista en Chile? La Nueva Acción Pública y el Partido Aprista Peruano (1931 1933)", Revista bistórica, №33, Lima, 2009.

Federico Duarte, "Imágenes de esperanza: la apropiación del ejemplo de la Revolución Cubana por los grupos de la izquierda brasileña en los años sesenta”, Izquierdas, N 4, 3, Santiago, 2009.

Fernando Casanueva y Manuel Fernández, El Partido Socialista y la lucha de clase en Chile, Santiago, Quimantú, 1973.

Florencia Peyrou y Darina, Martykanova, "La historia transnacional”, Revista Ayer, N² 2, 94, 2014.

Gabriel Salazar, Conversaciones con Carlos Altamirano. Memorias críticas. Santiago, Debate, 2011.

Gerardo Necoechea, "Experiencia, ideología y proceso de politización en las historias orales de militancia de izquierda durante la segunda mitad del siglo XX", Pablo Pozzi (coord.), Rebeldes e Inconformistas. Procesos de politización y rebelión en América Latina, Buenos Aires, CLACSO-ImagoMundi, 2016, 13-34.

Hernán Ramírez, Origen y formación del Partido Comunista de Chile, Santiago, Progreso, 1984.

Hernán Venegas, "El Partido Comunista de Chile y sus políticas aliancistas: Del frente popular a la unión nacional antifascista, 1935-1943, Revista de Historia Social y de las Mentalidades, N 14, Santiago, 2010.

---"El Partido Comunista de Chile: Antecedentes ideológicos de su estrategia hacia la Unidad Popular (1961.1970)", Revista de Historia Socialy de las Mentalidades, N 7, Santiago, 2003.

Horacio Tarcus, "El marxismo en América Latina y la problemática de la recepción transnacional de las ideas", Temas de nuestra América, N 54, Ciudad de México, 2013.

---“La historia intelectual y la problemática de la recepción”. Introducción del libro Marx en la Argentina. Sus primeros lectores obreros, intelectuales y cientificos (1871-1910), Buenos Aires, Siglo XXI, 2007.

Hugo Fazio, "La historia global y su conveniencia para el estudio del pasado y del presente", Historia Crítica, N³9 E, Bogotá, 2009.

Ignacio Walker, "Democracia, Populismo y Leninismo: El Partido Socialista de Chile (1933-1973)", Ignacio Walker, Socialismo y democracia. Chile y Europa en perspectiva comparada, CIEPLAN, Santiago, 1990. 
Isabel Torres, La crisis del sistema democrático: las elecciones presidenciales y los proyectos politicos excluyentes. Chile, 1958-1970, Santiago, Centro de Investigaciones Diego Barros Arana DIBAM-Editorial Universitaria, 2014.

Ivette Lozoya, “Theotonio Dos Santos, un intelectual revolucionario”, Izquierdas, Santiago, 25, 2015.

---"Pensar la Revolución: Pensamiento Latinoamericano e intelectuales en el MIR chileno. 1965-1973. Propuesta teórico metodológica para su estudio desde la Historia Intelectual y la Historia de la Violencia", Revista de Humanidades, 27, Santiago, 2013.

Jaime Massardo, La formación del imaginario politico de Luis Emilio Recabarren, Santiago, LOM, 2008.

Joaquín Fernández, "Nacionalismo y Marxismo en el Partido Socialista Popular (1948-1957)”, Izquierdas, 34, 2017.

---"En lucha contra el "pulmón de la conspiración fascista en América Latina". Los comunistas chilenos ante el proceso político argentino y el Gobierno de la Revolución de Junio (1943-1946)", Revista Historia, 48, II, 2015.

---“Allende, el allendismo y los partidos: El Frente de Acción Popular ante las elecciones presidenciales de 1958”, Izquierdas, № 23, Santiago, 2015.

---"Orígenes de un desencuentro: El Partido Comunista de Chile ante el Movimiento Nacionalista Revolucionario y la dictadura de Villarroel en Bolivia (1943-1946), Revista de Historia Social y de las Mentalidades, $\mathrm{N}^{\circ} 1,19,2015$.

---"Populismo, democracia y marxismo: el debate de la izquierda chilena y la candidatura presidencial de Salvador Allende en 1952". Finis Terrae, Revista de Humanidades 1, 2013.

Jorge Arrate y Eduardo Rojas, Memoria de la Izquierda Chilena (tomo 2), Santiago, Vergara editor, 2003.

Jorge Navarro, Revolucionarios y parlamentarios. Una cultura política del Partido Obrero Socialista, 1912-1922; Santiago, LOM, 2017.

José Bendicho, Comparación e historia transnacional: ¿cuál es su pertinencia para el estudio del hispanismo en Latinoamérica? Taller de Discusión "Las derechas en el Cono Sur, siglo XX”, Universidad Nacional de General Sarmiento, 2012.

José Ponce y Aníbal Pérez "La revitalización de la historiografía política chilena", POLIS revista Latinoamericana, 12, N³6, Santiago, 2013.

Juan Reveco, "Influencia del APRA en el Partido Socialista de Chile", Vida y obra de Víctor Raúl Haya de la Torre. Lima, Instituto Cambio y Desarrollo, 2006.

Juan Yañez, La OIT en América del Sur: El comunismo y los trabajadores chilenos (1922-1932), Santiago, Ediciones Universidad Alberto Hurtado, 2016.

Julio Faúndez, Izquierdas y democracia en Chile, 1932-1973, Santiago, BAT Ediciones, 1992.

Julio Jobet, El Partido Socialista de Chile, Santiago, Prensa Latinoamericana, 1972.

Julio Jobet y Alejandro Chelen, Pensamiento teórico y político del Partido Socialista de Chileno, Santiago, Editorial Quimantú, 1972.

Julio Pinto, Luis Emilio Recabarren. Una biografía histórica, Santiago, LOM, 2013. 
---“¿Y la historia les dio la razón? El MIR en dictadura, 1973-1981”, Verónica Valdivia, Rolando Álvarez y Julio Pinto. Su revolución contra nuestra revolución. Irquierdas y derechas en el Chile de Pinochet (1973-1981). Santiago, LOM, 2006.

Julio Pinto y Verónica Valdivia, ¿Revolución proletaria o querida chusma? Socialismo y alessandrismo en la pugna por la politización pampina (1911-1932), Santiago, LOM, 2001.

Leopoldo Benavides, La formación de la irquierda chilena. Relaciones entre el Partido Comunista y el Partido Socialista, Santiago, FLACSO, 1988.

Luis Corvalán, Del anticapitalismo al neoliberalismo: Izquierda, centro y derecha en la lucha entre los proyectos globales, 1950-2000, Santiago, Sudamericana, 2002.

Luis Ortega, "La radicalización de los socialistas de Chile en la Década de 1960", Universum, 23. 2, 2008. ---“Del Frente de Trabajadores al Congreso de Chillán. Los Socialistas de Chile entre 1956 y $1967 ”$. Revista Electrónica Palimpsesto, 1, 2003.

Marco González, "Comunismo chileno y cultura Frente Popular. Las representaciones de los comunistas chilenos a través de la revista Principios, 1935-1947”, Izquierdas, 11, Santiago, 2011.

María Coelho, "América Latina: Historia comparada, historias conectadas, historia transnacional", Anuario N²4, Revista Digital No 3, Rosario, 2011-2012.

María Pérez, "Redes y conexiones en la historia", Historia Crítica, N 55, Bogotá, 2015.

María Soledad Gómez, "Factores nacionales e internacionales de la política interna del Partido Comunista en Chile (1922-1952)”, Augusto Varas, Alfredo Riquelme y Marcelo Casals (ed), Santiago, Catalonia, 2010.

Mariano Vega, “¿Hidalguismo versus lafertismo? Crisis y disputa por la representación del comunismo en Chile, 1929-1933”, Olga Ulianova; Rolando Álvarez y Manuel Loyola (ed), 1912-2012 El Siglo de los Comunistas, Santiago, IDEA-USACH, 2012.

Mateus Filippa Meireles, Origens da Teoria Marxista da Dependência: o Centro de Estudos Socioeconômicos (CESO) da Universidade do Chile e a práxis de Ruy Mauro Marini, Vânia Bambirra e Theotonio dos Santos (1966-1973), Universidade Federal do Rio Grande do Sul, Departamento de História, Trabalho de Conclusão requisito parcial para a obtenção do grau de Licenciado em História, 2014.

Mauricio Archila, "La izquierda hoy: reflexiones sobre su identidad", Encuentro Marx Vive, Bogotá, Universidad Nacional, 2007.

Nicolás Acevedo, "La Voz del Campo, La Política Agraria del Partido Comunista durante el Frente Popular, 1936-1940”, Olga Ulianova; Rolando Álvarez y Manuel Loyola (ed), 1912-2012 El Siglo de los Comunistas, Santiago, IDEA-USACH, 2012.

Olga Ulianova, "La nueva inserción internacional del comunismo chileno tras el golpe militar", Alfredo Riquelme y Tanya Harmer, Chile y la guerra fría global, RIL Editores-Instituto de Historia UC, 2014.

---"El comunismo chileno a través de los archivos soviéticos". Augusto Varas et al. (comps), El Partido Comunista en Chile, Santiago, Catalonia/Usach/Flacso, 2010. 
---“La historia política está de vuelta”, Olga Ulianova (ed), Redes política y militancia. La historia política está de vuelta, Santiago, Ariadna-IDEA, 2009.

---"Relaciones Internacionales y redefiniciones en el socialismo chileno 1973-1979”, Revista Irquierdas, 4, 2009.

---"Reflexiones sobre la Guerra Fría desde el fin del mundo", Fernando Purcell, Alfredo Riquelme, Ampliando miradas, Chile y su historia en el tiempo global. Santiago, RIL-UC, 2009.

---“Inserción internacional del socialismo chileno 1933-1973", Olga Ulianova (ed), Redes política y militancia. La historia política está de vuelta, Santiago, Ariadna-IDEA, 2009.

---"Develando un mito: emisarios de la Internacional Comunista en Chile", Revista Historia, 41, V. I, 2008. ---"República Socialista y soviets en Chile. Seguimiento y evaluación de una ocasión revolucionaria perdida", Ulianova y Riquelme (Eds.), Chile en los archivos soviéticos, Tomo 2, Santiago, LOM/USACH/Centro de Investigaciones Barros Arana, 2009.

---“Una crisis escuchada como la obertura de la revolución”, Ulianova y Riquelme (Eds.), Chile en los archivos soviéticos, Tomo 2, Santiago, LOM/USACH/Centro de Investigaciones Barros Arana, 2009.

---“Entre el auge revolucionario y los abismos del sectarismo: el PC chileno y el Buró Sudamericano de la Internacional Comunista 1932-1933”, Rolando Álvarez, Augusto Samaniego, Hernán Venegas eds. Fragmentos de una historia. El Partido Comunista de Chile en el siglo XX. Democratización, clandestinidad, rebelión (1921-1994). Santiago, Ediciones ICAL, 2008

---“Levantamiento campesino de Lonquimay y la Internacional Comunista”, Estudios Públicos, $\mathrm{N}^{\circ}$ 89, Santiago, 2003.

---“El PC chileno durante la dictadura de Carlos Ibáñez (1927-1931): la primera clandestinidad y bolchevización estaliniana”, Boletín de la Academia Chilena de la Historia, No111, Santiago, 2002

Oliver Dabene, La Region Amérca Latine. Interdependance et changement politique, París, Presses de Sciences Po, 1997.

Pablo Garrido, "Un Frente de Trabajadores comandado por la clase obrera: El Partido Socialista Popular y las definiciones iniciales en torno a la política del Frente de Trabajadores, 1946 - 1957”, Izquierdas, 35, Santiago, 2017.

---"La contribución teórica de la Unidad Popular. Revolución y democracia en el programa de la Vía Chilena al Socialismo”, Izquierdas, N²1, Santiago, 2014.

Paul Drake, Socialismo y populismo en Chile, 1932-1970, Valparaíso, Universidad Católica de Valparaíso, 1992.

Paula Vidal, "La categoría de Igualdad en el Partido Comunista de Chile en los años 60", Izquierdas, $\mathrm{N}^{\circ}$ 9, Santiago, 2011.

Pedro Cadarso, Fundamentos Teóricos del Conflicto Social. Madrid, Siglo XXI, 2001.

Pollack, Benny y Hernán Rosenkraz, Revolutionary Socialdemocracy: The Chilean Socialist Party. Londres, Pinter, 1986.

Roberto Pittaluga, Soviets en Buenos Aires. La izquierda de la Argentina ante la revolución en Rusia, Buenos Aires, Prometeo Libros, 2015.

---"De profetas a demonios: Recepciones anarquistas de la Revolución Rusa (Argentina 1917-1924)", Sociohistórica, 11-12, 2002 
Rolando Álvarez, "La bolchevización del Partido Comunista de Chile: Antecedentes (1920-1927)", Patricio Herrera (Coordinador), El Comunismo en América Latina. Experiencias militantes, intelectuales y transnacionales (1917-1955), Valparaíso, Universidad de Valparaíso, 2018.

---"El Partido Comunista de Chile en la década de 1930: Entre “clase contra clase” y el Frente Popular", Pacarina del Sur, 8, 31, 2017.

---"Historia e historiografía del comunismo: debates y nuevos enfoques", Revista de Historia Social y de las Mentalidades, N², 21, Santiago, 2017.

---Arriba los pobres el mundo. Cultura e identidad politica del Partido Comunista de Chile entre democracia y dictadura. 1965-1990, Santiago, LOM, 2011.

---"Historias, historiografía y memorias del comunismo chileno en la primera década del siglo XXI", Viviana Bravo, ¡Con la razón y la fuerza, venceremos! La Rebelión Popular y la Subjetividad Comunista en los '80, Santiago, Ariadna Ediciones, 2010.

---“ ¡Viva la patria y la revolución! Partido Comunista y nacionalismo (1921-1926)”, Revista de Historia Social y de las Mentalidades, 7, 2003.

Romain Bertrand, ¡Historia global, historias conectadas: ¿un giro historiográfico?”, Prohistoria, Buenos Aires, $\mathrm{N}^{\circ} 24,2015$.

Sebastián Hernández, "Apristas en Chile: circuitos intelectuales y redes políticas durante los años 1930”, Revista de Historia y Geografia, No 31, Santiago, 2014.

Sebastián Rivera, "El otro exilio chileno en México y Guatemala, 1948-1951. Militancia transnacional en los orígenes de la guerra fría", HISTORLA N 50, vol. I, Santiago, 2017.

Sergio Grez, "Un episodio de las políticas del "tercer periodo" de la internacional Comunista: elecciones

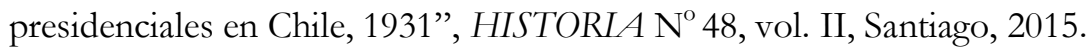

---“Comunismo chileno e Historiografía: un par de observaciones", Olga Ulianova; Rolando Álvarez y Manuel Loyola (editores), 1912 - 2012 El Siglo de los Comunistas, Santiago, IDEA-USACH, 2012.

---Historia del comunismo en Chile, Santiago, LOM, 2011.

---"Escribir la historia de los sectores populares. ¿Con o sin la política incluida? A propósito de dos miradas a la historia social", Revista Política, 44, Santiago, 2005.

Teresa Schneider, “O Exílio e as Transformações de Repertórios de Ação Coletiva: A Esquerda Brasileira no Chile e na França (1968-1978)", DADOS - Revista de Ciências Sociais, no 1, vol. 60, Rio de Janeiro, 2017.

Tomás Moulian, "Líneas estratégicas de la izquierda: "frentismo", populismo, antireformismo. 19331973", Santiago, FLACSO, 1982.

Tomás Moulian, Evolución Histórica de la izquierda chilena: Influencia del Marxismo, FLACSO, Documento de trabajo 139, Santiago, 1982.

Viviana Bravo, ¡Con la razón y la fuerza, venceremos! La Rebelión Popular y la Subjetividad Comunista en los '80. Santiago, Ariadna, 2010.

Ximena Urtubia, Hegemonía y Cultura Política en el Partido Comunista de Chile. La transformación del militante tradicional (1924-1933), Santiago, Ariadna, 2017. 